\title{
Comparison of banks of China and Australia by Return on Assets and Capital *
}

\author{
Evgeniia Rubinshtein, Maxim Saltykov, Artur \\ Nagapetyan \\ Department of Finance and Credit \\ Far Eastern Federal University \\ Vladivostok, Russia \\ fineasusual@mail.ru
}

\author{
Yulia Diachenko, Anna Brizitskaya \\ Department of World Economy \\ Far Eastern Federal University \\ Vladivostok, Russia
}

\begin{abstract}
Banking systems of two countries of APEC are the subject of the presented paper. Since 2014, Russia has been in partial isolation because the country is affected by the restrictive political and economic measures, so it becomes rational to strengthen economic relations with Asian countries. This region is very non-uniform: from the largest economies to microstates. Banking systems of such very different states, as the People's Republic of China and the Commonwealth of Australia were under consideration. More precise, the goal was to compare banking systems of two Asian countries, which are People's Republic of China and the Commonwealth of Australia, with respect to such economic indicators as return on assets and return on capital. Comparison in parameters Return on Assets and Return on Capital was carried out by two samples, representing the major banks of both countries. The methodology represents a statistical hypotheses test for variances and means. The result showed that with respect to Return on Assets and Return on Capital, two populations of banks are similar. The variables "Return on Capital" and "Return on Assets" are important for the manager, who makes decisions, and are in the line with standards of Basel Committee on Banking Supervision. Such approach could be applied to the research in different countries.
\end{abstract}

Keywords-banking systems; APEC members; Tier1 capital; statistical hypothesis testing; return on assets; return on capital

\section{INTRODUCTION}

This paper presents research on banks of the People's Republic of China (PRC) as representatives of banks of the region of the Asia-Pacific Economic Cooperation (APEC), which were compared to banks of Australia which are also members of APEC. The reason that the region of the AsiaPacific Economic Cooperation was chosen is that APEC is the regional organization with the unique structure of participants, including the countries on both sides of the Pacific Ocean. Now, when Russia is in partial isolation because of the restrictive political and economic measures introduced against Russia and a number of Russian persons, and the organizations which, according to the international organizations and certain countries, are involved in destabilization of a situation in Ukraine, the turn of Russian foreign economic relations towards the Asian countries is logical. The leadership of the USA was the initiator of imposition of sanctions for the purpose of the international isolation of Russia. Under their influence, the European Union countries, the states of the Big seven and some other countries which are partners of the USA and the EU joined sanctions.

\section{BACKGROUND}

The literature on the relationship between bank performance and capital structure describes different ideas.

In the context of factors within the control of management, the immediate factors, which would have an impact on bank profitability, would be those that affect bank's net interest income [1]. To this end, the net interest margin could be expected to have a positive influence on bank's profitability.

The higher value of Equity multiplier indicates greater risk for a bank. Samad and Hassan found that the higher returns might have been due to higher risky investments by the bank[2],[3]. This is supported by the increased debt equity and equity multiplier ratio.

Zhang and Daly applied the equity multiplier indicator; the results support claims that Chinese owned banks are the least profitable amongst foreign owned and local owned banks [4].

In his study, Dinger V. [5] suggested that in emerging economies, global banks also work with national banks. So due to transactional banks, the liquidity risk can be reduced. Because of normal conditions in the economy, these global banks hold low liquidity assets. But when the whole economy of that country is in crisis, they hold higher liquid assets as compared to the single market banks. Siddiqi also stated that the global financial crisis from 2008 to 2009 had impact on the capability of the third component (liquidity risk).

The study of Kyalaf Al - Taani [6] has found no statistically significant relationship between capital structure and firm performance. The study recommends that managers should be careful while using debt as a source of finance since a negative relationship exists between the capital structure and performance variables, used in this work.

Hadlock and James [7] suggest that corporations with a high level of profitability should use a high level of debts. In 
other words, they show a positive relation between performance and the capital structure.

Berríos, Myrna $\mathrm{R}$ [8] considers that higher loans to deposits ratio may be seen as a signal of lower liquidity due to greater amounts of cash given to borrowers relative to those received from depositors. When considering the results for the complete 200-observation data set, in general, there seems to be a positive relationship between the measure that represents lesser prudence in lending and financial performance.

According to Heiney [9], during the period from 2000 to 2005, there was an increase in Return on Assets (ROA) and a decrease inReturn on Equity (ROE) for banks in the United States. According to the results of a survey made among bank senior managers, the three risk factors that most contributed to the financial crisis were inappropriate risk governance, weak risk culture, and ineffective incentive and remuneration policies [10],[11].

The total debt to equity ratio is one of the determinants of bank profitability. For lower debt to equity ratios, higher debt of financing may motivate managerial behavior, resulting in decreased agency costs and, consequently, higher profitability. However, if debt levels reach a sufficiently high level, implying that equity financing is too low, there is no incentive for managers to act for shareholders' benefit and there will be alsoincreased costs related to debt financing, due to higher likelihood of bankruptcy. At these excessive debt levels, total debt to equity may be negatively related to profitability [12].

However, the findings of several studies suggest a positive relationship between higher debt levels and credit risk and a positive or insignificant relationship between higher debt levels and profitability. Using a regulatory asset risk-based measure for credit risk and an indirect measure for debt to equity (based on equity to risk based assets, where higher equity is equivalent to lower debt levels), Salah and Fedhila [13] found a negative relationship between equity levels and credit risk.

Corcoran [14] obtained similar results. Furthermore, Hsieh and Lee [15] uncovered a negative association between equity to assets and profitability. In turn, Gill, Biger, and Mathur [16] found no significant relationship between long-term debt to total assets and profitability for a group of companies in service industries. Debt and equity are the two main sources of capital for financing investment and operating activities.

One outstanding feature of the Australian banking system was the low level of nonperforming loans, which are those with payments in arrears. It did not face the great liquidity problems that arose elsewhere, and even though bank share prices declined due to the crisis, these decreases were not as large as those of their counterparts in other countries [17].

Hawtrey [17] argues that there are several explanations for this resilience. All of them have a common theme: better bank corporate governance. One explanation for bank resilience is a higher loan quality due to responsible lending practices. This, in turn, is a result of boards of directors and executives' prudence in lending decisions and avoidance of low quality debt securities. The predominance of the lower risk intermediation model (acceptance of deposits and approval of loans) over the higher risk securitization model (approval of mortgage loans and sale of securities backed by loan collections) has been advantageous to Australia. The stress on lending growth in relation to securitization allowed for higher long-term profitability. This benefit was complemented by a greater emphasis on prime lending - low risk bank borrowers - as opposed to subprime lending - high risk borrowers [17].

Even though prime lending has lower credit or default risk, Australian banks were better prepared by ensuring higher provision or reserve for loan losses, which, in turn, was greater than impaired loans (those with a high likelihood of default). Another strength related to bank capital (funds provided by shareholders and bank operations instead of depositors and other creditors) is superior to minimum amounts, based on asset risk [17].

Diversity and stability of sources of funds is essential to ensure their availability at not too high costs. This entailed not independence of mostly short-term and local sources, but rather relying more on long-term and global sources, when compared to banks in other countries [17]. Australian banks also resisted the temptation to focus on a short-term instead of a long-term horizon. A longer term focus avoids the search for rapid earnings and share prices' growth fueled by high risk decision making. Proper risk management was also enhanced by high quality of bank supervision through effectiveness of financial system regulation [17].

The share of APEC in world macroeconomic indicators is rather high. As official APEC sight shows, nearly a half of the entire land area and world economic activity, $2 / 5$ of the world population, more than a half of economic potential of the world economy is the share of the region consisting of 21 economies. Extreme heterogeneity is a feature of this region. The largest countries are the members of APEC. They are Russia, Canada, the USA, China and Australia. Besides there are the largest economies of the world on population, it is China, the USA, Indonesia, Russia, Japan, Mexico, on the one hand. And on the other hand, there are the microstates, such as Hong Kong, Singapore, Brunei. The importance of banks of the region is caused, first of all, by the bank organizations of the leading economies of APEC: The USA, China, Japan, Canada and Australia, almost all bank capacity of the region is concentrated there.

According to the data, presented in "The Banker" magazine the five of the largest banks of the world includes mostly Chinese and American banks, which have a great influence not only on a world financial system in general, but also on economy of the countries of APEC in particular. Indicators of their activity, in 2016 are shown in Tables 1 and 2. These data came from the service sight of Financial Times called "The Banker Database". 
TABLE I. INDICATORS OF ACTIVITY OF THE FIRST THREE APEC LARGEST BANKS IN 2016

\begin{tabular}{|l|l|l|c|}
\hline Bank & $\begin{array}{l}\text { Industrial and } \\
\text { Commercial } \\
\text { Bank of China } \\
\text { (PRC) }\end{array}$ & $\begin{array}{l}\text { China } \\
\text { Construction } \\
\text { Bank (PRC) }\end{array}$ & $\begin{array}{l}\text { JP Morgan } \\
\text { Chase and } \\
\text { Co (USA) }\end{array}$ \\
\hline $\begin{array}{l}\text { Assets, trillion US } \\
\text { dollars }\end{array}$ & 3.42 & 2.83 & 2.49 \\
\hline $\begin{array}{l}\text { Tier 1 capital of } \\
\text { bank, bln. dollars of } \\
\text { the USA }\end{array}$ & 274.43 & 220.01 & 208.11 \\
\hline ROA,\% & 1.64 & 1.63 & 1.39 \\
\hline CAR, \% & 8.02 & 7.78 & 8.35 \\
\hline
\end{tabular}

TABLE II. INDICATORS OF ACTIVITY OF THE FOURTH AND FIFTH APEC LARGEST BANKS IN 2016

\begin{tabular}{|l|l|c|}
\hline Bank & $\begin{array}{l}\text { Bank of China } \\
\text { (PRC) }\end{array}$ & $\begin{array}{c}\text { Agricultural Bank of } \\
\text { China (PRC) }\end{array}$ \\
\hline $\begin{array}{l}\text { Assets, trillion US } \\
\text { dollars }\end{array}$ & 2.59 & 2.74 \\
\hline $\begin{array}{l}\text { Tier 1 capital of } \\
\text { bank, bln. dollars of } \\
\text { the USA }\end{array}$ & 198.07 & 185.61 \\
\hline ROA,\% & 1.38 & 1.30 \\
\hline CAR, \% & 7.64 & 6.77 \\
\hline
\end{tabular}

The international bank regulators agreed on the provision on introduction of additional requirements to sufficiency of the capital for global financial institutions which are systemically significant, that are the largest transnational banks on which stability of a world financial system depends.

The rating of 20 banks is shown in Table 3 . The banks are located in a decreasing order of an indicator of sufficiency of the capital or an indicator "the capital of the first level" (Tier 1 Capital), which is a key measure of financial stability of any bank according to the Basel agreement. These data came also from the website "The Banker Database".

TABLE III. THE FIRST 34 LARGEST BANKS OF THE WORLD AT THE LEVEL OF SUFFICIENCY OF THE CAPITAL (TIER 1 CAPITAL) IN 2016 ACCORDING TO TOP 1000 WORLD BANKS 2016

\begin{tabular}{|l|l|l|l|}
\hline $\begin{array}{l}\text { Rating } \\
\mathbf{2 0 1 6}\end{array}$ & $\begin{array}{l}\text { Rating } \\
\mathbf{2 0 1 5}\end{array}$ & \multicolumn{1}{|c|}{ The name of a bank } & Country \\
\hline 1 & 1 & ICBC & PRC \\
\hline 2 & 2 & $\begin{array}{l}\text { China Construction Bank } \\
\text { Corporation }\end{array}$ & PRC \\
\hline 3 & 3 & JP Morgan Chase \& Co & USA \\
\hline 4 & 4 & Bank of China & PRC \\
\hline 5 & 6 & Agricultural Bank of China & PRC \\
\hline 6 & 5 & Bank of America & USA \\
\hline 7 & 7 & Citigroup & USA \\
\hline 8 & 8 & Wells Fargo \& Co & USA \\
\hline 9 & 9 & HSBC Holdings & UK \\
\hline 10 & 10 & Mitsubishi UFJ Financial Group & Japan \\
\hline 11 & 11 & Credit Agricole & France \\
\hline 12 & 12 & BNP Paribas & France \\
\hline 13 & 17 & Bank of Communications & PRC \\
\hline 14 & 14 & Goldman Sachs & USA \\
\hline 15 & 19 & Sumitomo Mitsui Financial Group & Japan \\
\hline 16 & 15 & Banco Santander & Spain \\
\hline 17 & 13 & Barclays & UK \\
\hline 18 & 21 & Mizuho Financial Group & Japan \\
\hline 19 & 18 & RBS & UK \\
\hline & & & \\
\hline
\end{tabular}

\begin{tabular}{|l|l|l|l|}
\hline 20 & 20 & Morgan Stanley & USA \\
\hline 21 & 16 & Deutsche Bank & Germany \\
\hline 22 & 23 & Groupe BPCE & France \\
\hline 23 & 29 & Norinchukin Bank & Japan \\
\hline 24 & 22 & Lloyds Banking Group & UK \\
\hline 25 & 24 & SocieteGenerale & France \\
\hline 26 & 27 & Credit Suisse Group & Switzerland \\
\hline 27 & 28 & China Merchants Group & China \\
\hline 28 & 26 & BBNA & Spain \\
\hline 29 & 35 & Shanghai Pudong Development Bank & China \\
\hline 30 & 33 & China Citic Bank & China \\
\hline 31 & 25 & Unicredit & Italy \\
\hline 32 & 36 & Industrial Bank & China \\
\hline 33 & 38 & China Minsheng Bank & China \\
\hline 34 & 32 & ING Bank & Netherlands \\
\hline
\end{tabular}

Let us consider briefly a banking system of the People's Republic of China. The modern banking system of China has two levels: the top level is presented by the National Bank of China which is the Central bank of the country, the lower level - by the different types of specialized banks which are:

- national commercial banks,

- joint stock banks,

- political banks,

- regional (city) commercial banks,

- foreign banks.

Let us consider these groups in more detail.

- national commercial banks (Industrial and Commercial Bank of China, Agricultural bank of China, China Construction Bank, Bank of China, Bank of Communications);

They were created as a result of transformation of National Bank of China to the Central bank and moved from the function of crediting separate branches of the national economy to specialized state banks. $49.2 \%$ of assets of the banking system of the People's Republic of China fall to the share of five largest banks. Till 2005 they belonged to the government, but then they were incorporated. The major part belongs to the government, represented by the central government, or the state agencies.

- joint stock banks;

$15.6 \%$ of assets fall to the share of twelve other banks.

- political banks (Agricultural Development Bank of China (ADB); China Development Bank (CDB), Export-Import Bank of China (CEB);

There are just three banks with $100 \%$ of shares of the central government, they make $8 \%$ of total bank assets and have strictly assigned certain functions: ADB concentrates on agriculture, $\mathrm{CDB}$ - on infrastructure projects, $\mathrm{CEB}$ - on support to export of goods of advanced processing and import of hi-tech tools.

- regional (city) commercial banks;

In the category of rural (11.2\% of assets) and city ( $8.2 \%$ of assets) banks, there are a few thousands of organizations. Usually, their activity is limited by the territory of the city or 
the municipal region, and the local government often acts as the founder, but not always has the majority in the share capital.

\section{- foreign banks (1.8\% of assets of a banking system).}

The banking sector of China since 1978 is in the process of reforming - transition from the completely state system to the competitive market with representation of different banks, including foreign, and financial products. Nevertheless, central and the local governments still keep considerable influence on activity of banks.

The following Banks of China were investigated: Industrial and Commercial Bank of China (ICBC), China Construction Bank Corporation, Bank of China, Agricultural Bank of China, Bank of Communications, China CITIC Bank, China Merchants Bank, which belong to the group of national commercial banks.

As for a banking system of Australia, it has a two-level system which is presented by the Central bank (Reserve bank of Australia) and various categories of commercial banks:

- the main commercial banks - banks of "Big Four" (Commonwealth Bank of Australia, National Australia Bank, Australia and New Zealand (ANZ) Banking Group, Westpac Banking Corporation);

These banks are universal and provide all range of banking services to clients.

- regional banks (banks of states);

The small commercial banks operating in a certain state or a segment of the market, the majority of them are created with participation of the foreign capital.

- branches of foreign banks.

65 banks, including 21 national banks and 44 - with participation of the foreign capital ( 8 subsidiary banks and 36 branches) worked in Australia in 2016.

The banking sector has the high level of concentration, its basis is made by four largest commercial banks (Big Four), $90 \%$ of all deposits and the credits are the share of these banks.

The banking system of Australia has a great influence on development of a banking system of New Zealand: four of five largest banks of this country belong to the Australian banks.

This paper investigates the following banks of Australia: National Australia Bank, ANZ Banking Group, Commonwealth Bank of Australia, that is, those banks, which belong to the main commercial banks.

\section{RESEARCH METHODOLOGY}

The authors investigated two groups of banks:

- the main commercial banks of theCommonwealth of Australia, they are Commonwealth Bank of Australia, National Australia Bank, Australia and New Zealand (ANZ) Banking Group, Westpac Banking Corporation;
- The national commercial banks of the People's Republic of China. They are (Industrial and Commercial Bank of China, Agricultural bank of China, China Construction Bank, Bank of China, Bank of Communications.

The authors made a comparison of banks by two indicators of efficiency of bank activity. These indicators are:

- return on assets,

- return on capital.

These indicators are dimensionless and are measured in percent. Therefore, it is quite correct to use them for an assessment and comparison of various banks. It is especially relevant when the presented banks belong to the group of universal commercial banks.

The methodology represents test of statistical hypotheses. The first step was the test for comparison of variances for two corresponding groups of banks, one from China and another one from Australia. It was made in order to find out what type of test for averages should be done after that. Then a test of a hypothesis for equality of means of two populations was carried out.

Let us compare two groups of banks, using the test of a statistical hypothesis on equality of two population means [18]. So the authors' goal is to check whether these two groups came from the same population. At first, let us test equality of the variances for these two groups, and after that let us test equality of means.

At the beginning, the test for equality of variances of Return on Assets of both groups was carried out [19], [20].

For testing, claiming about variances, the authors assume that samples came from the populations, which are normally distributed.

The hypotheses are:

$$
\begin{aligned}
& \mathrm{H}_{0}: \sigma_{1}{ }^{2}=\sigma_{2}{ }^{2} \\
& \mathrm{H}_{\mathrm{a}}: \sigma_{1}{ }^{2} \neq \sigma_{2}{ }^{2},
\end{aligned}
$$

where $\sigma_{1}^{2}$ is the variance of the Return on Assets for the Australian banks, $\sigma_{2}$ is the variance of the Return on Assets for the Chinese banks.

The test statistic is $\mathrm{F}=\mathrm{s}_{1}{ }^{2} / \mathrm{s}_{2}{ }^{2}=1.258$, with numerator degrees of freedom of 2 and denominator degrees of freedom of 6 , where $s_{1}{ }^{2}$ is the sample variance of the Return on Assets for the Australian banks; $s_{2}{ }^{2}$ is the sample variance of the Return on Assets for the Chinese banks.

The authors chose the significance level of 0,05 . At a given level of significance, the test showed that the variances of Return on Assets for two groups can be considered equal as $\mathrm{p}$ - value for one tailed test was 0.3498, which is larger than the significance level. That means that $\mathrm{H}_{0}$ is accepted.

Then the authors tested the equality of means. If means for both groups will be the same, then both samples came from the same population and with respect to Return on Assets both bank groups are the same.

The hypotheses are: 


$$
\begin{array}{ll}
\mathrm{H}_{0}: & \mu_{1}=\mu_{2} \\
\mathrm{H}_{\mathrm{a}}: & \mu_{1} \neq \mu_{2},
\end{array}
$$

where $\mu_{1}$ is the mean of the Return on Assets for the Australian banks, $\mu_{2}$ is the mean of the Return on Assets for the Chinese banks.

As the authors found, the test for equality of means for Return on Assets for banks of China and Australia can be carried out with the assumption of equality of variances of two populations [21]. Then the test statistic is:

$$
\mathrm{t}=\left(\mathrm{x}_{1}-\mathrm{x}_{2}\right) /\left(\mathrm{s}_{\mathrm{p}}{ }^{2} / \mathrm{n}_{1}+\mathrm{s}_{\mathrm{p}}{ }^{2} / \mathrm{n}_{2}\right)^{0,5},
$$

where $x_{1}$ is the sample mean of the Return on Assets for the Australian banks, $x_{2}$ is the sample mean of the Return on Assets for the Chinese banks, $\mathrm{s}_{\mathrm{p}}{ }^{2}$ is a pooled estimate of the common variance $\sigma^{2}$. This estimate is calculated as

$$
\mathrm{s}_{\mathrm{p}}^{2}=\left(\left(\mathrm{n}_{1}-1\right) \mathrm{s}_{1}^{2}+\left(\mathrm{n}_{2}-1\right) \mathrm{s}_{2}^{2}\right) /\left(\mathrm{n}_{1}+\mathrm{n}_{2}-2\right),
$$

where $s_{1}{ }^{2}$ is the sample variance of the Return on Assets for the Australian banks, $\mathrm{s}_{2}{ }^{2}$ is the sample variance of the Return on Assets for the Chinese banks, $\mathrm{n}_{1}$ is the sample size of the Return on Assets for the Australian banks, $n_{2}$ is the sample size of the Return on Assets for the Chinese banks. The value for the degrees of freedom is $n_{1}+n_{2}-2$.

The value of test statistics is $-1,16$, with degrees of freedom of 8. P-value for this two-tailed test - 0,280. At the significance level of 0.05 , the result of testing showed that means of Return on Assets of two populations are the same, because $\mathrm{p}$ - value is greater than the significance level, so let us accept $\mathrm{H}_{0}$.

The next step is hypothesis test for equality of variances of Return on Capital for the both groups was carried out.

Again, the authors used hypothesis, stated in (1), with assumption that both samples of Return on Capital came from the populations, which are normally distributed. The difference is the following: $\sigma_{1}{ }^{2}$ is the variance of the Return on Capital for the Australian banks; $\sigma_{2}$ is the variance of the Return on Capital for the Chinese banks.

Test statistic is the same with value $\mathrm{F}=\mathrm{s}_{1}{ }^{2} / \mathrm{s}_{2}{ }^{2}=10.074$, with numerator degrees of freedom of 2 and denominator degrees of freedom of 6 , where $s_{1}{ }^{2}$ is the sample variance of the Return on Capital for theAustralian banks, $\mathrm{s}_{2}{ }^{2}$ is the sample variance of the Return on Capital for theChinese banks.

The significance level for this test was 0.05 as usual for this research. By the indicator Return on Capital, the test for equality of variances showed that the variances of Return on Capital cannot be considered equal, $\mathrm{p}$ - value for one tailed test was 0.0121, which is less than the significance level. Thus, one can carry out the test for equality of means of two populations with the assumption of unequal variances. That means that one rejects $\mathrm{H}_{0}$ and accepts $\mathrm{H}_{\mathrm{a}}$ from formula (1).

The third step was hypothesis testing on equality of means of two populations in the form, stated in (2), where $\mu_{1}$ is the meanof the Return on Capital for the Australian banks, $\mu_{2}$ is the meanof the Return on Capital for theChinese banks.
This test was carried out with the assumption of unequal variances. Then the test statistic is:

$$
\mathrm{t}=\left(\mathrm{x}_{1}-\mathrm{x}_{2}\right) /\left(\mathrm{s}_{1}{ }^{2} / \mathrm{n}_{1}+\mathrm{s}_{2}{ }^{2} / \mathrm{n}_{2}\right)^{0,5},
$$

with degrees of freedom equal to the smaller number from $\left\{\left(\mathrm{n}_{1}-1\right),\left(\mathrm{n}_{2}-1\right)\right\}$. In this case, it was 2 .

The value of test statistics is 1,26 , with degrees of freedom of 2. P-value for this two-tailed test is 0,335. At the significance level of 0.05 , the result of testing showed that means of Return on Capital of two populations are the same because $\mathrm{p}$ - value is greater than significance level, so let us accept $\mathrm{H}_{0}$, and means of these two populations can be considered equal.

\section{RESULTS OF ANALYSIS}

Thus, there are the following results. First, the authors tested the equality of variances for the variable "return on assets", which showed that variances of Return on Assets for both countries could be considered as equal with $\mathrm{p}$-value of 0,3498 for one tailed test.

Second, the authors tested the equality of variances for the variable "return on capital", which showed that variances of Return on Capital for both countries should be considered as unequal, with p-value of 0.0121 for one tailed test.

After that, we could proceed to the hypothesis testing on equality of means.

The third step was to test hypothesis on equality of means for variable "Return on Assets". The test showed that the means of these two populations of banks are the same, with pvalue of 0.2796 for two-tailed test.

The finishing step was to check hypothesis on equality of means for variable "Return on Capital". The test showed that the means of these two populations of banks are equal, with pvalue of 0.3347 for two-tailed test.

Therefore, despite internal deep distinctions of economies of the People's Republic of China and the Commonwealth of Australia, national commercial banks of China and the main commercial banks of Australia have something the general. At least, one can state about such indicators as Return on Assets, that they belong to the same population. The authors can consider both variances and means of these populations as equal.

By the indicator Return on Capital, one can consider variances unequal, but means of two populations are equal, so populations are different.

\section{CONCLUSIONS}

The reports of International Monetary Fund showed that since 2014, the volume of national economic production per year in China exceeds the same of the USA according to purchasing power parity. 16 years ago, the USA made three times more than China. In spite of the fact that the economy of China can be considered as the world's largest - the country is now yet not the richest - Gross Domestic Product (GDP) per capita in China makes about one eights of the level of the USA. 
The economy of Australia is one of the largest economic systems in the world with GDP per capita just 17\% less than that for the USA. In 2016, Australia had the 13th place in the rating of the largest national economies according to nominal GDP.

It is possible to consider that irrespective of deep distinctions in economies, state systems of the People's Republics of China and the Commonwealth of Australia, the groups of the largest banks of these two countries belong to one large group of banks with respect to the parameter Return on Assets, their distinctions are statistically not significant. On parameter Return on Capital, these groups are various. The fact that means of these two bank populations are equal is quite important. It means that, on average, the Return on Capital for both groups is the same. But the variability of this parameter for these two groups is very different. The variance of Return on Capital for the group of Australian banks is much higher than the variance of Return on Capital for the group of Chinese banks.

\section{REFERENCES}

[1] B. K. Guru,S. Vaithilingam, N. Ismail, "Electronic banking in Malaysia: a note on evolution of services and consumer reactions,"in Journal of Internet Banking and Commerce,5 (1), pp. 234-256, 2000.

[2] A. Samad, M. K. Hassan, "The performance of Malaysian Islamic bank during 1984-1997: an exploratory study," in Thoughts on Economics, vol. 10(1-2), pp. 7-26, 2000.

[3] L. Wang, A. Nagapetyan, E. Lutsenko and V. Pakhmutov, "Theory and methodology for financial infrastructure of foreign direct investment in developing countries: The BRICS case," in International Review of Management and Marketing,vol 6(S1), pp. 179-183.

[4] X. Zhang,K. Daly, "Performance of China-owned banks in Hong Kong", in International Journal of Banking and Finance 9(3), Article 6, 2012.

[5] V. Dinger, 2009. "Do foreign-owned banks affect banking system liquidity risk?” J. Comp. Econ, 2009, pp. 647-657.

[6] Khalaf Al-Taani,"The Relationship between Capital Structure and Firm Performance: Evidence from Jordan", in Journal of Finance and Accounting, 1(3), pp. 41-45, 2013.
[7] C. Hadlock,C.James, "Do banks provide financial slack?"in Journal of Finance, vol. 57, pp. 1383-420, 2002.

[8] R. Berríos, Myrna, "The Relationship between Bank Credit Risk and Profitability and Liquidity,"in The International Journal of Business and Finance Research, vol. 7 (3),pp. 105-118, 2013.

[9] J. N.Heiney, "Consolidation and Profitability in the U.S. Banking Industry,"in Journal of Business \& Economics Research, vol. 8(1), pp. 93-98, 2010.

[10] J. Hashagen, N. Harman, M. Conover, J. Sharma, "Risk Management in Banking: Beyond the Credit Crisis,"in Journal of Structured Finance, vol. 15(1), pp. 92-103, 2009.

[11] A. Nagapetyan, E. Rubinshtein, "Comparison of positive and negative risk indices as a tool for portfolio management," in Actual Problems of Economics, vol 7, pp. 142-150, 2016.

[12] S. H. Paolo, "Determinants of the Profitability of the US Banking Industry," in International Journal of Business and Social Science, vol. 2(22), pp. 255-269, 2011.

[13] N. B. Salah, H.Fedhila, "Effects of Securitization on Credit Risk and Banking Stability: Empirical Evidence from American Commercial Banks," in International Journal of Economics and Finance, vol. 4(5), , pp. 194-207, 2012

[14] C. Corcoran,"Reassessment of Regulated Bank Capital on Profitability and Risk," in International Business \& Economics Research Journal, vol. 9(3), pp. 97-100, 2010.

[15] M.-F.Hsieh, C.-C. Lee, "The Puzzle between Banking Competition and Profitability can be Solved: International Evidence from Bank-level Data," in Journal of Financial Services Research, vol. 38, pp. 135-157, 2010.

[16] A. Gill,N.Biger, N. Mathur,"The Effect of Capital Structure on Profitability: Evidence from the United States," in International Journal of Management, vol. 28(4), pp. 3-15, 2011.

[17] K. Hawtrey, "The Global Credit Crisis: Why Have Australian Banks Been So Remarkably Resilient?" in Journal of Policy Analysis and Reform, vol. 16(3), pp. 95-114, 2009.

[18] S. David Moore, P. George McCabe, Introduction to the Practice of Statistics, W. H. Freeman and Company, 2006.

[19] D. Waters, Quantitative Methods for Business, Prentice Hall, 2001.

[20] E. Rubinshtein, A. Srivastava, "Optimal linear projections for enhancing desired data statistics," in Statistics and Computing,vol. 20 (3), pp.267$282,2010$.

[21] J. L. Devore, Probability and Statistics for Engineering and Sciences, Thomson Brooks- Cole, 2004 